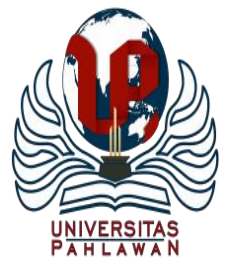

Edukatif : Jurnal Ilmu Pendidikan Volume 3 Nomor 5 Tahun 2021 Halm 1971 - 1981

EDUKATIF: JURNAL ILMU PENDIDIKAN

Research \& Learning in Education

https://edukatif.org/index.php/edukatif/index

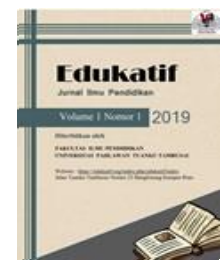

\title{
Tradition of Cleaning For Reacting Social, Religion and Environment Education
}

\author{
Bahagia $^{1 凶}$, Fachruddin Majeri Mangunjaya $^{2}$, Rimun Wibowo $^{3}$, Zulkifli Rangkuti ${ }^{4}$, \\ Zakky Muhammad Noor ${ }^{5}$ \\ Universitas Ibn Khaldun Bogor, Indonesia ${ }^{1,}$ Universitas Nasional Jakarta, Indonesia ${ }^{2}$ \\ STIMMA IMMI Jakarta, Indonesia ${ }^{3,4}$, LPM Equator Bogor,Indonesia ${ }^{5}$

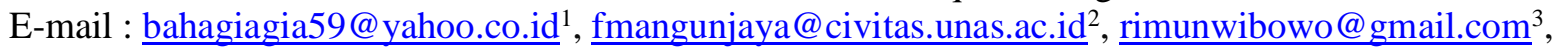 \\ zrangkuti@gmail.com ${ }^{4}$
}

\begin{abstract}
Abstrak
Penelitian ini bertujuan untuk menyelidiki nilai tradisi membersihkan untuk pendidikan. Metode penelitian menggunakan pendekatan kualitatif etnografi. Metode ini digunakan karenaberkaitan dengan masyarakat dan budaya serta tradisi masyarakat. Untuk mengumpulkan data digunakan sebagai wawancara mendalam. Sampel dipilih melalui teknik purposive. Hasilnya teliti dengan cara teknik triangulasi dan sumber triangulasi. Hasil penelitian menunjukkan masyarakat masih melestarikan tradisi dan budaya bersih-bersih di tengah globalisasi untuk mempererat hubungan sosial dan menyelamatkan masyarakat dari penyakit akibat kebersihan yang buruk serta menghindarkan masyarakat dari bencana alam. Selain itu, masyarakat menjadikan bank sampah sebagai cara untuk mengurangi sampah organik dan membuang sampah organik karena masyarakat mengubur sampah organik di lubang biopori. Disamping itu, masyarakat dapat memanfaatkan hasil olahannya sebagai pupuk organik dan berperen untuk menyerap air hujan sehingga bisa mengatasi banjir. Selanjutnya, tradisi bersih-bersih memiliki pendidikan sosial karena tradisi tersebut sebagai keteladanan bagi generasi muda untuk melanjutkan kebiasaan ini di masa depan dan sebagai model untuk membangun solidaritas sosial antar masyarakat. Selain itu juga terdapat pendidikan lingkungan karena masyarakat harus belajar untuk peduli terhadap lingkungan alam melalui kebersihan alam dan secara religius, tradisi tersebut terkait karena agama mengajarkan kepada masyarakat untuk melakukan kebersihan lingkungan, tubuh, rumah dan tempat peribadahan.
\end{abstract}

Keywords: Bersih-Bersih, Lingkungan, Pendidikan, social, agama and tradisi

\begin{abstract}
This research aims to investigate the tradition of cleaning value for education. The research method uses an ethnographic qualitative approach. This method is implied because this research is related to society and culture as well as the tradition of community. To gather data was used as an in-depth interview. Sample are selected through purposive technique. The result is probed meticulously through the triangulation technique and triangulation sources. The result shows the societies still preserve cleaning tradition to tighten the social connection and save the societies from an ailment which is impacted by poor hygiene as well as avoiding from a natural disaster. Another is societies make garbage banks as the method to reduce an-organic sewage and decline organic garbage because the societies bury organic sewage in biopori holes. As a result, It can combat natural disasters. The other is there is social education because the tradition is exemplary to the young generation to continue this habit in the future and as a model to build social solidarity among societies. It also has environmental education because the societies have to learn to care about the environment and religious values. After all, religion teaches the societies to perform hygiene in the environment, body, house, and the place for worship.
\end{abstract}

Keywords: Cleaning, Environment, Education, Social, Religion and tradition

Copyright (c) 2021

Bahagia, Fachruddin Majeri Mangunjaya, Rimun Wibowo, Zulkifli Rangkuti, Zakky Muhammad Noor

Corresponding author:

Email : bahagiagia59@yahoo.co.id

DOI : https://doi.org/10.31004/edukatif.v3i5.666

ISSN 2656-8063 (Media Cetak)

ISSN 2656-8071 (Media Online)

Edukatif : Jurnal Ilmu Pendidikan Vol 3 No 5 Tahun 2021 p-ISSN 2656-8063 e-ISSN 2656-8071 
1972 Tradition of Cleaning For Reacting Social, Religion and Environment Education - Bahagia, Fachruddin Majeri Mangunjaya, Rimun Wibowo, Zulkifli Rangkuti, Zakky Muhammad Noor

DOI: https://doi.org/10.31004/edukatif.v3i5.666

\section{INTRODUCTION}

Cleaning is the habit of societies in Indonesia country. It has embedded in human behavior and soul in the countryside. Taryatman (2016) said that clean and healthy living behavior is a set of behaviors that are practiced based on awareness as a result of learning which makes individuals/families/groups can help themselves in the health sector and play an active role in realizing degrees public health. Iskandar (2018) reported that environmental cleanliness is the cleanliness of a place to live, workplace, and various public facilities. Tradition and cleaning behavior has been as culture in Indonesia and the activity release in collective behavior but it is uncommon to perform individually despite the mutual working in cleaning for environment almost continue to vanish in the housing area. Tradition is a cultural heritage and habit in the previous period which is preserved until nowadays. Cooperation is a tradition of mutual assistance in various ways including building houses, providing food, and working together to solve problems, based on group interests compared to individuals. Cooperation also builds social resilience because in its implementation it is very much supported by social relations in groups, collective strength, not individuals, fostering individual awareness towards collective or collective awareness, and the existence of rules in cooperation activities.

Fusnika \& Tyas (2018) describe several values in cooperative activities, including the value of togetherness, the value of unity, the value of belonging, the value of willingness to report, and the value of helping to help. There are many real activities of cooperation, such as working hand in hand in cleaning public facilities, worship, and women also play a role together in providing food sources (Khozim, 2020). Rolitia et al. (2016) explained that cooperation activities foster togetherness in carrying out their roles and duties, cooperation also provides a value of happiness by helping to help and community service, when one community gets a disaster another community will consciously help and provide assistance without having to be asked. Therefore, in social life, there needs to be cooperation in solving all problems because cooperation is a characteristic of Indonesian local wisdom which shows social cohesion in social solidarity and social interaction (Irfan, 2017). The form of cooperation is a cleaning tradition in the community which has been embedded in the countryside. It also has a connection to the local knowledge of people in rural areas. To give a clear example, in Dusun Sambek they know the tradition is cleaning village tradition.

The role is to tighten social solidarity. There is some activity in social solidarity including pay dues, mutual working in the cleaning of the village, and party. The members of the community who don't participate, the person receive the punishment socially and direct reprimand (Maytisa, 2016). Sunyoto (2018) reveals that this tradition has local cultural values including responsibility, willingness to sacrifice, unity or harmony, cooperation, respect, respect, religion, spirituality, and aesthetics. Even this tradition can preserve the ecological balance to ensure water can be used as irrigation of agriculture and guarantee clean water (Damiasih \& Damayanti, 2016). Meanwhile, Cathrin (2017) reveals that the major reason for cleaning traditional ceremony contains elements of and cultural factors and noble values that can guide life which is good for the successors. In applicating, the tradition of hygiene can't neglect the role of women in this activity, actin unable to release without assisting by women. The role of women provided food such as yellow rice (Setyowati \& Hanif, 2014).

The tradition of cleaning results in to increase in the rate of human health because cleaning can be categorized to indicate human health. Meaning that women in the cleaning tradition have a crucial role to participate and women can work in public without receiving marginalization and discrimination. It shows that it is responsible for women and men. Directly, there is social value as education in mutual working in cleaning. Umar (2017) said that apart from that social value is something valuable (useful/useful) associated with the relationship between humans, and its role in the development of general education in the sense of developing and fostering the personality as a whole show an atmosphere of democracy, cooperation, please help and positive exemplary, so that human beings who have awareness are created of himself as a creature 
1973 Tradition of Cleaning For Reacting Social, Religion and Environment Education - Bahagia, Fachruddin Majeri Mangunjaya, Rimun Wibowo, Zulkifli Rangkuti, Zakky Muhammad Noor

DOI: https://doi.org/10.31004/edukatif.v3i5.666

created by Allah SWT as an individual, social, and citizens of even good citizens of the world. Environment education is another advantage of this tradition because there is a linkage between humans and the environment such as soil, water, trees, and bushes.

Sulistyo (2018) remarks that environmental education is expected to be a vehicle to educate the general public and learners, in particular, to better understand the global environmental crisis phenomenon and foster an attitude to be more concerned with the environment, by internalizing religious values. Jufri et al.(2018) remark that environmental education must be based on immediate experiences with nature, it can establish behavior, value, and habituation in a saving environment. Then, in creating a friendly environment, the behavior must be created continuously through daily activity in every day. The goal of environmental education is to learn from nature to nurture the environment (Muhyidin Nurzaelani, 2017). The tradition of hygiene has connected to environment education because the societies comprehend directly to applicate the real action to strengthen the role of nature for bolstering human life. It makes them conscious that humans need an environment and jumps the rate of awareness to nature because human life relies on the environment. The cleanliness of the residence is done by wiping the windows and household furniture, sweeping and mopping floors, washing cooking utensils and cutlery (eg with ashes), cleaning bathrooms and latrines, as well as disposing of trash.

As the condition of sanitation is worst, it refers to the rise of ailment which is caused by a messy and filthy environment. One impacted ailment which is through bad sanitation is scabies. Cletus, P. Santoso (2014) said that scabies is a disease caused by insufficient maintained personal hygiene and environmental sanitation the less good ones. Environmental cleanliness starts from maintaining cleaning the yard and gutters and clearing the street in front of the house of trash. The other pivotal malady which is caused by poor hygiene are acute respiratory infections (ARI) and diarrhea are the two main diseases caused by an unsanitary environment. Additionally, fever dengue can be mentioned as another ailment that is considered with hygiene in the environment. Mosquito especially Aedes aegypti exert a poor hygiene environment as a place for life habitat and nesting. Ningsih (2020) reveals that there is a relationship between the presence of ventilation gauze, solid waste, the presence of larvae with the incidence of dengue fever (DHF), and there is no relationship between water storage and the incidence of dengue fever.

Zakiudin \& Shaluhiyah (2016) said that clean culture is a reflection of attitudes and behavior in society maintain and maintain cleanliness personal and environmental in life daily. To implement the cleaning behavior, The role of the individual and the citizen is very much needed in creating a clean and healthy environment by keeping the environment clean physical, processing RT waste, using latrines, washing hands, bathing, and maintaining the cleanliness of organs femininity, because a clean environment depends on behavior (Mailoa et al., 2017). Humans need to maintain environmental cleanliness and personal hygiene so that everyone is healthy must be very clever to maintain cleanliness, it is not difficult to keep the environment clean, there are many kinds of ways to keep the environment clean, for example by throwing garbage on the place, always cleaning water gutters, separating dry trash and wet rubbish, diligently sweep the yard, recycle unused items and much more (Idawati et al., 2020). Furthermore, the cleaning tradition can be connected to religious values.

Sulistyo (2018)said that recognizing the role of the human as a caliph who is in charge of safeguarding and managing nature and the consequences of damaging the environment in terms of Islamic perspective is expected to arouse public awareness to participate actively in maintaining, managing wisely and preserving the surrounding environment. For example, Islamic religion motivates the human to conduct cleaning activity to bolster worship action. Hidayati (2019) remarked that God commanded people to keep clean because God likes those who purify themselves. By purifying oneself keeping clean will create an environment healthy and clean life. In this research, the research will not investigate the previous research discovering but the research desire to find out some of the aims including How the cleaning tradition is released in the social environment 
1974 Tradition of Cleaning For Reacting Social, Religion and Environment Education - Bahagia, Fachruddin Majeri Mangunjaya, Rimun Wibowo, Zulkifli Rangkuti, Zakky Muhammad Noor

DOI: https://doi.org/10.31004/edukatif.v3i5.666

(societies) and what sorts of advantage for the environment in societies perspective, the second is to discover the relation of garbage bank and tradition of cleaning as well as the benefit of garbage bank for societies, thirdly to find out about social education in cleaning tradition and bank of garbage for societies as well as environment and religion.

\section{METHODS}

The research Tradition of Cleaning For Reacting Social, Religion And Environment Education. The Research is conducted in Tanah Sareal district, Taman Cimangu, Bogor West Java. The research method used is the ethnography qualitative approach because research intent to discover about the tradition in previous time but it can continue recently in society. Ethnography can literally mean writing or reporting about an ethnic group. The characteristics of this ethnographic field research method are its holistic-integrative nature, thick description, and qualitative analysis to obtain the cultural owner's point of view (native's point of view). Ethnographic research is the product of multiple practices. It is an assemblage of seeing and looking, hearing and listening, handling objects, describing, interviewing, recording, reading, documenting, and working with data transcribing, storing, transforming, sharing, labeling, coding, sequencing, comparing, interpreting, visualizing, and quoting as well as many other practices (Ploder \& Hamann, 2021). Ishtiaq (2019) said that data collection procedures in qualitative research have been divided into four basic types qualitative observation, qualitative interviews, qualitative documents, and qualitative audio and visual materials. To select the sample, the research uses purposive technique sampling. This sampling technique is used because determining the sample with some pondering including the key person of society such as the Chairman of the neighborhood namely Abah Jumli and the head of the garbage bank namely Nuriati. They have implemented and as the motivator of people in the countryside. They also the movement for people to embroil the activity both cleaning tradition and bank of garbage. The data are selected comprising the behavior of hygiene tradition as culture in a rural area to combat human life problem like ailment which is caused by poor sanitation as well as the form of cleaning tradition activity in a social environment. The other data are gathered to have a connection to the tradition for social relations like solidarity among the societies. It continues to collect some data which is treating with the role of bank of garbage to combat disaster as well as to boost the cleaning tradition. It must be supported by the social and economic value of garbage for societies as well as the function of hygiene tradition to combat flooding and environmental obstacle.

The other data is to link the tradition of cleaning and education based on societies in numerous perspective education such as environment education, social and religious values. Triangulation is implied to test the result. Triangulation is often thought of as a way of checking out insights 94 Introduction to Qualitative Research Methods gleaned from different informants or different sources of data. By drawing on other types and sources of data, observers also gain a deeper and clearer understanding of the setting and people being studied. Practically all participant-observers conduct some form of interviews and analyze written documents during or after their field research. Especially toward the end of the research, after the observer has established relationships with people and has gained insider knowledge, open-ended interviews with informants can be relatively focused and specific (Taylor, Bogdan \& DeVault, 2016). Observation must be conducted because to see the location and the real action of cities. The data which have been collected from in-depth-interview must be combined with another method like observation and documentation. When data is collected in the morning, respondents still fresh and it distinguishes as garnishing data in the evening while the triangulation technique is to exert a variety of ways. In this research, the combination from numerous sources including in-depth-interview, observation, and documentation can be reliable data. 
1975 Tradition of Cleaning For Reacting Social, Religion and Environment Education - Bahagia, Fachruddin Majeri Mangunjaya, Rimun Wibowo, Zulkifli Rangkuti, Zakky Muhammad Noor

DOI: https://doi.org/10.31004/edukatif.v3i5.666

\section{RESULT AND DISCUSSION}

The tradition of mutual working and mutual assisting has essential value in societies typically for environment education and disaster for the young generation. Environment and humans can be separated from, human health endures on environmental health. Mutual working in a rural area like in Cimanggu village still preserves the tradition amid globalization. The members of societies have a schedule to allocate their time for working together in the cleaning of the environment in the vicinity of their house. The location is different from a housing estate in the city where the people rare to find their work together for cleaning upriver and water culvert. The generation performs this activity from a previous time ago. It is conducted again nowadays. Tradition can be categorized as tradition as the activity is conducted continuously. The people must mingle in cooperation despite their busy with individual working but each member always distributes some time to work with the group. From the head of the village perspective, it has related to awareness of individual to their environment where the members are conscious that they must contribute their power to clean their environment. Each people never invite and the head of the rural area never impels the person who has not mixed in cooperation activity. Even no social punishment from the societies despite individual hesitates to joint with. However, the person must be involved willingly without any enforcement. It connects to the culture which has been handed down from their generation and it is a part of their daily habit.

It makes an individual think that they will feel sick as they don't work with the ingroup. Work cooperation in the cleaning of the environment from any organic garbage is conducted each month. There is some activity in cooperation such as normalization of the river to ensure that the flow of river streams down properly. The purpose is to evade flooding to the house environment and improve the river environment as well as to preserve the quality of water. As a result, flooding ecocatastrophe can be surmounted through work in a group. Besides cleaning up the stream of the river, the societies also derive the grass which is disturbed the river area. The other goal of this activity in the respondent's view it can decline the attack of fever dengue which is a mosquito as the vector of the virus. It makes people avoid some of the diseases. Dengue hemorrhagic fever is a disease caused by the Dengue virus which is transmitted to humans through the bite of an Aedes sp. Mosquito infected with the Dengue virus (Nadifah et al., 2017). The other location which it can location of breeding is a container, tub, old tires, bottles, coconut shells, buckets, cups, flower pots, bowls scars, brown skin, cans, drums, trash cans, and fish ponds (Zen, 2013).

Additionally, the waterway in front of the house streams better because erosion of land and garbage are picked by the people. The other activity is to wipe the organic garbage such as leaves and death of branch trees and clean the mosque. It refers to abolish the nest of mosquitoes in the vicinity of housing. The activity also performs in several areas which have potential as a place for mosquito nestings such as empty house and land as well as tidy up some of the bushes under big tress because it makes the environment very shady and messy. The mosquito intent to take the egg in this area. In addition, in the head of the perspective, the death of leaf which contains rainwater has potential as a nest of mosquito as well as a messy place. As the environment is filthy, the breeding of mosquitoes can't be avoided. It becomes the best habitat for this insect. Many factors fascinate female mosquitoes to take their egg such as the rate of temperature, the light, and the condition of the environment (Hendri et al., 2010). While Agustin (2017) said that mosquito has its breeding site in clearwater areas such as in the bathwater containers, flower pots, pet containers as well as in the used goods that can hold stagnant water. To release the activity, the societies provide manual appliances such as knives and hoe. They work in the morning until daylight.

Usually, they work at 08 a.m. Once the cleaning and clearing activity is completed, the mother of the household rendering some of the food to the man. There is cooperation in separating the task between women and men in cooperation, especially in cleaning the environment. The awareness of working together in the clearing of environment unable to release as a relation in the group is not strong. The head of the village namely Jumli said that they perceive that a healthy environment is one priority in their societies and relations 
1976 Tradition of Cleaning For Reacting Social, Religion and Environment Education - Bahagia, Fachruddin Majeri Mangunjaya, Rimun Wibowo, Zulkifli Rangkuti, Zakky Muhammad Noor DOI: https://doi.org/10.31004/edukatif.v3i5.666

of the family are essential to practice that value in the environment. As the person perceives the neighbor or another person as their family, they will mutually assist and working. Meanwhile, as the person won't feel that the neighbor is not crucial from their life, they reluctant to mingle with. The impact is the people more individual, it is not found in this location. Then, activity like garbage bank is performed because they are aware that sewage is a big obstacle for humans. The societies have been educated by the head of the garbage bank namely Nuriati to separate the sorts of rubbish. Member of societies can select whether organic and inorganic garbage. An-Organic garbage such as a bottle of plastic must be split before giving to the garbage bank. Immediately, the societies literate which the garbage can be categorized as organic and in-organic sewage. There are at least two patterns including the societies store their plastic garbage to the bank of the garbage but they don't get money directly and the societies save garbage but they immediately obtain money from plastic bottle sales.

At least three of the objectives in garbage banks, including societies, can gain income like money from the garbage of banks. It can assist the subsistences of the family as well as helping family economies. Even though it is temporary but it is quite valuable. The societies choose two mechanisms in this situation that encompasses receiving directly the money or save the money in a garbage bank. The people will accept the money after the saving is abandon of money from trading plastic garbage. Event some of the money from processed garbage sales allocate to the orphan community. Nuriati reveals that the sewage which has been collected in the bank of garbage will be picked by the garbage collector to process another step like recycle of bottle garbage. The amount of sewage is taken by garbage pickers two times a month. The number of garbage processed each month can reach 1000 kilograms in a month for in-organic garbage. Meanwhile, the price of one kilogram of plastic garbage like an instant drink bottle is about RP. 4500-6000. while the price for instant drink glass after it is cleaned, the price higher than a bottle of plastic is around RP. 7500. Once the garbage has been sold, the bank of sewage possess IDR 4500,000-600,000 each month. For organic sewage, the societies don't sales it but they decay organic rubbish in biopori holes. Then, the yield of composting can be used as manure to support greening activity in the vicinity of a location.

As domestic litter doesn't process, it impacts human health (Meilani et al., 2020). The societies exert it as manure for refining the condition of plant-like rural gardening. As a result, the rain can be absorbed underground because bio pores make the soil more fertile. It can raise the capacity of the land to absorb water and avoids flooding disasters (Sudiana et al., 2020). Biopori also has a role in reducing inundation, water stock underground, and decline the amount of garbage as well as creating organic fertilizer (Karyanto et al., 2020). The activity also has benefits like rise the knowledge and skills of societies in applying appropriate technology (Langoy et al., 2021). However, another discovery that sewage especially organic has not processed properly. Harahap (2016) reveals that most of the organic garbage is disposed of by inhabitants and collected by a cleaning clerk, after that the rubbish is burned. Besides, it has benefits to the environment, it can be valuable also for the social environment. Nuriati said that it can tighten social relations among the household mothers and societies around the bank of garbage as well as ensure a healthy environment for the people.

Astutik (2013) said that the interaction which is based on a similar aim results in stringent cooperation between them. Cooperation among them gets stronger because there is a common goal. The impact is household mother builds trust among them. Even though the societies let their savings of money in the bank of garbage, they don't worry as their economic resources are smoked by the chief of the garbage bank. While trusting is the main capital to sustain their community for facing an obstacle in the next future. As the capital of trusting is weaken, it refers to the productivity of the community (Cahyono et al., 2018). However, the advantage of garbage in developing societies, garbage has a detrimental effect on the environment both organic and and-organic trash harm our environment. Human receives the adverse impact of inorganic thrash such as cancer and human body tissue damaged (Karuniastuti, 2013). Even it refers to inconvenient situations 
1977 Tradition of Cleaning For Reacting Social, Religion and Environment Education - Bahagia, Fachruddin Majeri Mangunjaya, Rimun Wibowo, Zulkifli Rangkuti, Zakky Muhammad Noor

DOI: https://doi.org/10.31004/edukatif.v3i5.666

such as bad smell, river pollution, and disturbs human health (Arisandi et al., 2020). Additionally, it can educate societies that garbage can't be mixed. The activity like mutual working tradition and environment has several social and environmental education in respondent perspective. To begin with, the young generation must be performed the exemplary.

The existences of modeling are better than theory which gives in class to raise the awareness of people in the cleaning environment. To release this, the older ask to the young generation to mix with some activity. The tradition of cleaning has been conducted in societies as exemplary to the young generation for ensuring that they must join the activity. It is bolstered by exemplary learning must show proper temper without improper example (Hidayat, 2015). Also, something is imitated by an individual who comes from another person that has a fortune value (Taklimudin \& Saputra, 2018). Sitompul (2016) said that habituation and imitation or exemplary are presented as methods that are appropriate and affect the formation of attitudes. When young people join, it can be embedded into the soul. The more young people willing to include the activity, the more young people conscious that they have the responsibility to other people practically in public need like cleaning. They will be ashamed if they go somewhere but their friend works for public like cleaning activity. The young generation and societies don't necessary to obtain training like material in class like formal school but they can see the exemplary in their environment.

Based on interviews with the head of societies namely Jumli remark that as this example still preserves, it can educate the societies and young generation that societies are essential for sustaining life. Young people have limitations to discover the example, tradition of cleaning in the environment as a good example for them.

Life can't be separated from another person, we need another person and we also need another person again. It is a time for us to join in social work for our goal. To release this, each month elder people try to conserve the cleaning tradition as the best sample for young people. The young generation may not join in the first time but the other time, young people blend to elder as the consequences as the young people participate without inviting and impelling. This method can be mentioned as exemplary learning to the person who learns about the environment. An exemplary model is to show a good temper to a learner who has a goal where the learner follows this example (Rubini, 2019). Cooperation in cleaning environments such as a river, in front of house, mosque, and the water of way as a method to give example to them without giving theory because it releases through action or behavior. Mustofa (2019) reveals that with examples of speech, deeds, and good behavior in any case, then it is amaliah the most memorable, both for students and in life human association.

Meaning that, as our tradition vanishes from our environment, it results to increase disaster, and the environment can be unhealthy because garbage can't be overcome and flooding comes to us as well as the fever dengue can hit the human. The other is young people and societies comprehend the linkage between mosquitoes, garbage, and flooding. Immediately, without having class training, they can experience for a long time ago never meet with some of disease and disaster. The other value is the conservation of tradition from extinction amid the state of art in globalization. Mutual working in cleaning can be categorized as a tradition because the actin has been conducted by the previous generation but it continues to nowaday people. It can vanish as no longer the activity is existence in a social environment. Furthermore, cooperation in the cleaning environment can strengthen social binding, mutual respect, and increase social solidarity in societies. It has some merits, as the people never meet, they can negative perception about the one people, it different when they people have a time to slight talking in work. Improving social relations through cooperation in the cleaning of the environment is essential as the person is very busy with their daily activity. It enables to comprehend comprehensively about the condition of neighbors whether they life is wealthy or under destitute. The circumstances can determine the action to aid in abolishing the miserable situation in our neighborhood.

When interview, Jumli said that it is possible for to someone speaks openly about the situation of their family at home because we are family. Even cooperation like cleaning is the best method to work collectively and understand how to adjust the team where each people have a different perspective. Here, we finish the 
1978 Tradition of Cleaning For Reacting Social, Religion and Environment Education - Bahagia, Fachruddin Majeri Mangunjaya, Rimun Wibowo, Zulkifli Rangkuti, Zakky Muhammad Noor

DOI: https://doi.org/10.31004/edukatif.v3i5.666

work without any conflict. It is also proof that women and men can mutually work in different sorts of work. It shows that women and men attain equality in social work in public space and no discrimination and marginalization of women power for contributing to the environment. Lastly, it can close humans to the environment where the human need environment and humans must salvage environment function to encourage human life. The head of the neighbor said that the environment is a major need for humans, as we preserve the environment, it can be valuable for us because the environment can save our life. To give a clear example is to clean river refer to salvage human from disease. It must be bolstered by religious education in cleaning tradition. In the head of a village point of view remark that Islam is a religion where pay attention to cleanliness and cleanliness as part of our worship. As we are intent to receive our worship, we must clear our environment, where we settle, mosque and environment.

Moreover, Islam has instructed us that cleaning is the basis of worship, if we would like to perform worship, we must clean our bodies. It is similar to Sumiati's perspective the cleaning is a part of belief and our health. As we desire health, we must clean our environment. Similarly, a filthy environment results in rising sorts of human diseases. Scabies is one treacherous ailment. Saputra et al (2019) It is an itching disease itching is caused by mites or fleas that cause a rash and redness on the skin that attacks the community. Furthermore, cleaning is an indicator of the quality of belief. Shalehah \& Salamah (2017) remarked that the Islamic religion clean religion that teaches us to look after cleanliness, cleanliness is referred to here as the cleanliness of eating, cleanliness drinking, house cleanliness, cleanliness water sources, yards, and roads because cleanliness in Islam is faith. It has a strong linkage to the relation between humans and the environment. Hidayati (2019)said that an environment is also a place for their interaction between a human with human, and a human with nature. Quality human health can be seen from the environment they live, when an environment looks clean and tidy then it can be judged that the humans who live around it are healthy human beings.

\section{CONCLUSION}

This tradition plays a role in maintaining social life as social relations between citizens can be stronger and also maintain a level of solidarity between community members. Then, the tradition of cleaning also plays a role in protecting human health from various diseases such as dengue fever caused by mosquitoes. In addition, this tradition can prevent people from various natural disasters such as floods because cleaning activities are carried out in various places ranging from river areas, residential areas, village parks, and places of worship as well as uninhabited houses. After that, the cleaning tradition was also supported by other activities such as a waste bank. Waste banks have economic value for residents because they can save in the form of waste in exchange for money so that they can increase their family's income. The waste bank is only to accommodate organic waste and inorganic waste used as fertilizer by inserting it into the biopore hole. The benefit is to prevent flooding and also produce organic fertilizers. From an education perspective, it creates social education because people try to comprehend each other socially and understand the hardship situation of their neighbors. Lastly, it stimulates education environment because human aware that human need most to nature and cleaning is part of faith religiously.

\section{REFERENCES}

Agustin, I. (2017). Perilaku Bertelur Dan Siklus Hidup Aedes aegypti Pada Berbagai Media Air. Jurnal Biologi, 6(4), 71-81.

Arisandi, A., Farid, A., \& Muskaromah, S. (2020). Pengelolaan Sampah Plastik yang Mencemari Saluran Irigasi Sungai Tonjung Kabupaten Bangkalan Madura. Jurnal Ilmiah Pangabdhi, 6(2), 54-58. https://doi.org/10.21107/pangabdhi.v6i2.7493

Astutik, J. (2013). Pola Relasi Sosial Dalam Implementas Program Nasional Pemberdayaan Masyarakat 
1979 Tradition of Cleaning For Reacting Social, Religion and Environment Education - Bahagia, Fachruddin Majeri Mangunjaya, Rimun Wibowo, Zulkifli Rangkuti, Zakky Muhammad Noor DOI: https://doi.org/10.31004/edukatif.v3i5.666

Mandiri Perkotaan (Pnpm-Mp) Di Kota Malang. Jurnal Humanity, 8(2), 30-50.

Cahyono, B., Studi, D., Pedagang, P., Kawasan, D. I., Jordan, Azhari, F., Mawardi, M. K., Astuti, W. P., Gandhiadi, G. K., Dharmawan, K., \& Kencana, I. P. E. N. (2018). Peran Modal Sosial Dalam Pengembangan Jaringan Usaha Kecil Menengah (Studi Kasus pada Rumah Makan Padang). Pendidikan Ilmu Pengetahuan Sosial, 59(1), 153-162. https://doi.org/10.1017/CBO9781107415324.004

Cathrin, S. (2017). Tinjauan Filsafat Kebudayaan Terhadap Upacara Adat Bersih-Desa Di Desa Tawun, Kecamatan Kasreman, Kabupaten Ngawi, Jawa Timur. Jurnal Filsafat, 27(1), 30-64. https://doi.org/10.22146/jf.22841

Cletus, P. Santoso, R. (2014). Studi Tungau Kudis Sarcoptes scabiei dan Perilaku Hidup Bersih dan Sehat (PHBS) di Wilayah Kecamatan Lekok Kabupaten Pasuruan Jawa Timur. Jurnal Vektora, 6, 33-40.

Damiasih, D., \& Damayanti, S. D. (2016). Pelestarian Tradisi Upacara Bersih Desa Sendang Tirto Sinongko Sebagai Wisata Budaya Di Klaten Jawa Tengah. Kepariwisataan: Jurnal Ilmiah, 10(1), 27-32.

Fusnika, F., \& Tyas, D. K. (2018). Menumbuhkan Kembali Budaya Kee'rja Banyau Sebagai Nilai Luhur Masyarakat Desa Sungai Deras Kecamatan Ketungau Hilir Kabupaten Sintang. VOX EDUKASI: Jurnal Ilmiah Ilmu Pendidikan, 9(2), 111-120. https://doi.org/10.31932/ve.v9i2.136

Harahap, R. D. (2016). Pengaruh Sampah Rumah Tangga Terhadap Pelestarian Lingkungan Ditinjau Dari Aspek Biologi Di Komplek Perumahan Graha Pertiwi Kel. Urung Kompas Kec. Rantau Selatan Effect Of Household Waste Viewed From The Aspect Environmental Conservation Biology In Housin. Cahaya Pendidikan, 2(1), 92-104. https://doi.org/10.33373/chypend.v2i1.609

Hendri, J., RES, R. N., \& Prasetyowati, H. (2010). Tempat Perkembangbiakan Nyamuk Aedes spp. Di Pasar Wisata Pangandaran. Aspirator: Journal of Vector Borne Diseases Studies, 2(1), 23-31. https://doi.org/10.22435/aspirator.v2i1.2940.

Hidayat, N. (2015). Metode Keteladanan dalam Pendidikan Islam. Ta 'allum: Jurnal Pendidikan Islam, 03(02), 135-150. https://doi.org/10.21274/taalum.2015.3.2.135-150

Hidayati, P. N. (2019). Perilaku Hidup Bersih Dan Sehat (Phbs) Sesuai Ajaran Islam Siswa Kelas V Mi Maarif Dukuh. Elementary: Islamic Teacher Journal, 7(1), 38-54. https://doi.org/10.21043/elementary.v7i1.4417

Idawati, Yuliana, Rahmi, P. T., Zuhra, F., \& Nurrahmah. (2020). Perilaku hidup bersih dan sehat (phbs) tentang kebersihan lingkungan di desa belee busu dusun meunasah dayah kecamatan mutiara barat kabupaten pidie. Communnity Development Journal, 1(3), 341-349.

Irfan, M. (2017). Metamorfosis gotong royong dalam pandangan konstruksi sosial. Prosiding Penelitian Dan Pengabdian Kepada Masyarakat, 4(1), 1-10.

Iskandar, A. A. (2018). Pentingnya Memelihara Kebersihan Dan Keamanan Lingkungan Secarapartisipatif Demi Meningkatkan Gotong Royong Dan Kualitas Hidup Warga. Jurnal Ilmiah Pena: Sains Dan Ilmu Pendidikan, 10(1), 79-84.

Ishtiaq, M. (2019). Book Review Creswell, J. W. (2014). Research Design: Qualitative, Quantitative and Mixed Methods Approaches (4th ed.). Thousand Oaks, CA: Sage. English Language Teaching 12 (5):40-41.

Jufri, Fua, J. La, \& Nurlila, R. U. (2018). Pendidikan Lingkungan Di Sekolah Dasar Negeri 1 Baruga Kota Kendari. Al-Ta'dib.

Karuniastuti, N. (2013). Bahaya Plastik terhadap Kesehatan dan Lingkungan. Swara Patra: Majalah Pusdiklat Migas, 3(1), 6-14.

Karyanto, B., Hermawati, A., \& Putri, C. F. (2020). Program Sumur Resapan Biopori Jumbo Sebagai Solusi Mengatasi Banjir Di Kelurahan Sumur Pacing Kecamatan Karawaci Kota Tangerang Provinsi Banten. Jurnal Aplikasi Dan Inovasi Ipteks "Soliditas” (J-Solid), 3(1), 12-17. 
1980 Tradition of Cleaning For Reacting Social, Religion and Environment Education - Bahagia, Fachruddin Majeri Mangunjaya, Rimun Wibowo, Zulkifli Rangkuti, Zakky Muhammad Noor DOI: https://doi.org/10.31004/edukatif.v3i5.666

https://doi.org/10.31328/js.v3i1.1386

Khozim, A. A. (2020). Perubahan Pola Kehidupan Masyarakat Asli Terhadap Pertumbuhan Industri Tekstil Di Desa Lojikobong Kecamatan Sumberjaya Kabupaten Majalengka. Etos: Jurnal Pengabdian Masyarakat, 2(2), 71-88. https://doi.org/10.47453/etos.v2i2.212

Langoy, M., Katili, D. Y., \& Umboh, S. D. (2021). Aplikasi Teknologi Tepat Guna Dalam Pencegahan Banjir Dengan Pembuatan Lubang Resapan Biopori Bagi Para Ibu Di Kelurahan Pandu Kecamatan Bunaken. JPAI: Jurnal Perempuan Dan Anak Indonesia, 2(2), 18-23. https://doi.org/10.35801/jpai.2.2.2021.32339

Mailoa, A. V., Kurniasari, M. D., \& Messakh, T. S. (2017). Persepsi warga mengenai perilaku hidup bersih dan sehat di Dusun Kebonan, Semarang. Masyarakat, Kebudayaan Dan Politik, 30(3), 229-236. https://doi.org/10.20473/mkp.v30i32017.229-236

Maytisa, D. (2016). Tayuban Dan Tradisi Bersih Desa Di Wonogiri (Studi Deskriptif Kualitatif Pada Masyarakat Dusun Sambeng, Desa Kepuhsari, Kecamatan Manyaran). UNS (Sebelas MMaret University).

Meilani, S., Kartika, W., \& Navanti, D. (2020). Peningkatan Resapan Air Hujan dan Reduksi Sampah Organik di Wilayah Permukiman dengan Pembuatan Lubang Resapan Biopori. Jurnal Sains Teknologi Dalam Pemberdayaan Masyarakat, 1(2), 1-6.

Muhyidin Nurzaelani, M. (2017). Peran Guru Dalam Pendidikan Lingkungan Hidup. Jurnal Teknologi Pendidikan, 6(1), 45-68. https://doi.org/10.32832/tek.pend.v6i1.503

Mustofa, A. (2019). Metode Keteladanan Perspektif Pendidikan Islam. Cendekia: Jurnal Studi Keislaman, 5(1), 23-42. https://doi.org/10.37348/cendekia.v5i1.71

Nadifah, F., Farida Muhajir, N., Arisandi, D., \& D. Owa Lobo, M. (2017). Identifikasi Larva Nyamuk Pada Tempat Penampungan Air Di Padukuhan Dero Condong Catur Kabupaten Sleman. Jurnal Kesehatan Masyarakat Andalas, 10(2), 172-178. https://doi.org/10.24893/jkma.v10i2.203

Ningsih, G. M. (2020). Puasa dan Solidaritas Sosial di Tengah Pandemi Covid-19. Arsip Publikasi Ilmiah Biro Administrasi Akademik.

Rolitia, M., Achdiani, Y., \& Eridiana, W. (2016). Nilai Gotong Royong Untuk Memperkuat Solidaritas Dalam Kehidupan Masyarakat Kampung Naga. Societas, 6(1).

Rubini, R. (2019). Metode Pembelajaran Berbasis Hadis. Humanika, XVIII(1), 31-49. https://doi.org/10.21831/hum.v18i1.23127

Saputra, R., Rahayu, W., \& Putri, R. M. (2019). Hubungan Perilaku Hidup Bersih Dan Sehat (PHBS) Dengan Timbulnya Penyakit Scabies Pada Santri. Nursing News, 4(1), 41-53.

Setyowati, A., \& Hanif, M. (2014). Peran Perempuan Dalam Tradisi Upacara Bersih Desa (Studi Kasus Di Desa Kiringan Kecamatan Takeran Kabupaten Magetan). Agastya: Jurnal Sejarah Dan Pembelajarannya, 4(1), 1-21. https://doi.org/10.25273/ajsp.v4i01.819

Shalehah, S., \& Salamah, S. (2017). Penanaman Nilai-Nilai Kebersihan Lingkungan Oleh Guru Di MI Hayatuddiniyah Jambu Burung Kecamatan Benruntung Baru Kabupaten Banjar. Pendidikan Guru Madrasah Ibtidaiyah Ilmiah, VII(01), 145-166.

Siddiq, M., \& Salama, H. (2019). Etnografi Sebagai Teori Dan Metode. Kordinat: Jurnal Komunikasi Antar Perguruan Tinggi Agama Islam, 8(1), 23-48. https://doi.org/10.15408/kordinat.v18i1.11471

Sudiana, I. K., Sudiarta, I. W., \& Sukajaya, I. N. (2020). Pendidikan Dan Pelatihan Pembuatan Lubang Resapan Biopori (Lrb) Kepada Masyarakat Desa Sambangan Kecamatan Buleleng Kabupaten Buleleng. Proceeding Senadimas Undiksha.

Sulistyo, A. (2018). Konsep Pendidikan Lingkungan Hidup Dalam Pandangan Islam. Cahaya Pendidikan, 4(1), 45-58. https://doi.org/10.33373/chypend.v4i1.1281 
1981 Tradition of Cleaning For Reacting Social, Religion and Environment Education - Bahagia, Fachruddin Majeri Mangunjaya, Rimun Wibowo, Zulkifli Rangkuti, Zakky Muhammad Noor DOI: https://doi.org/10.31004/edukatif.v3i5.666

Sunyoto, S. (2018). Tradisi Bersih Kali (Studi Kearifan Lokal Dan Potensinya Sebagai Sumber Pembelajaran Ips Sd. Gulawentah:Jurnal Studi Sosial, 3(2), 79-89. https://doi.org/10.25273/gulawentah.v3i2.3164

Ploder, A., \& Hamann, J. (2021). Practices Of Ethnographic Research: Introduction To The Special Issue. Journal Of Contemporary Ethnography 50(1):3-10

Taklimudin, T., \& Saputra, F. (2018). Metode Keteladanan Pendidikan Islam dalam Persfektif Quran. BELAJEA: Jurnal Pendidikan Islam, 3(1), 1-22. https://doi.org/10.29240/bjpi.v3i1.383

Taryatman. (2016). Budaya Hidup Bersih Dan Sehat Di Sekolah Dasar Untuk Membangun Genersi Muda Yang Berkarakter. Trihayu: Jurnal Pendidikan Ke-SD-An, 3(1), 8-13.

Taylor, S.J., Bogdan, R., \&. DeVault, M.L. (2016). Introduction To Qualitative Research Methods A Guidebook And Resource. Canada: Wiley.

Umar, J. (2017). Peranan Nilai Sosial dalam Pengembangan Pendidikan Umum. Al-Idarah Jurnal Kependidikan Islam, 5(1), 1-18.

Zakiudin, A., \& Shaluhiyah, Z. (2016). Perilaku Kebersihan Diri (Personal Hygiene) Santri di Pondok Pesantren Wilayah Kabupaten Brebes akan Terwujud Jika Didukung dengan Ketersediaan Sarana Prasarana. Jurnal Promosi Kesehatan Indonesia, 11(2), 64-83. https://doi.org/10.14710/jpki.11.2.64-83

Zen, S. (2013). Studi Ekologi Tempat Berkembangbiak Nyamuk Aedes Sp Di Kota Metro Sebagai Sumber Belajar Biologi Materi Pokok Insekta. Bioedukasi (Jurnal Pendidikan Biologi), 4(2), 1-5. https://doi.org/10.24127/bioedukasi.v4i2.231 